\section{Análise farmacognóstica da droga e do extrato fluido das folhas de Symphytum officinale L. (Boraginaceae)}

Toledo, A.C.O. 1; Duarte, M.R. ${ }^{2}$; Nakashima, T. ${ }^{2 *}$

1 Mestranda em Botânica, Universidade Federal do Paraná

${ }^{2}$ Departamento de Farmácia, Universidade Federal do Paraná leaves. It was proceeded to the morphological and anatomical identification to foliate of the medicinal plant and the vegetable drug was submitted to the determination of water, dry residue and total and insoluble ashes in acid. The etanolic and aqueous extracts were rehearsed in triplicate, with relationship to the sensorial analysis, $\mathrm{pH}$ determination and dry residue, detection of chemical groups and quantification of the beginning active allantoin.

As plantas medicinais sempre exerceram papel importante no tratamento de doenças e algumas delas têm se mostrado efetivas quando os fármacos de origem sintética, oriundos da medicina ocidental, não funcionam ou não se mostram eficazes ${ }^{1}$. Os padrões estabelecidos para matérias-primas de origem vegetal usualmente são mais complexos do que para matérias-primas sintéticas, uma vez que o conjunto de determinações abrange o teor de substâncias ativas e as características físicoquímicas e microbiológicas, de acordo com a finalidade de uso.

Symphytum officinale L. é originário da Europa (Portugal e Inglaterra) e da Ásia temperada, naturalizado nos Estados Unidos e América do Sul e conhecido popularmente no Brasil como confrei, consolda-maior, consólida-maior, orelha-de-asno, erva-do-cardeal, língua-de-vaca e orelha-de-burro ${ }^{2,3}$.

Em estudo morfo-anatômico, a folha apresentouse discolor, oval-oblonga ou lanceolada, longamente peciolada, com ápice agudo-acuminado, base atenuada ou cuneada e margens sinuosas, medindo cerca de 15$40 \mathrm{~cm} \mathrm{x} \mathrm{4-12} \mathrm{cm.} \mathrm{A} \mathrm{epiderme} \mathrm{é} \mathrm{uniestratificada} \mathrm{e,} \mathrm{em}$ ambas as faces; exibe células de parede anticlinal sinuosa, estômatos anomocíticos e anisocíticos, e numerosos tricomas tectores unicelulares retos e alguns glandulares. Observam-se também tricomas tectores unciformes unicelulares na face abaxial. O mesofilo é dorsiventral, os feixes vasculares são colaterais e a nervura central é biconvexa. Esta é percorrida por um a aproximadamente oito feixes vasculares mergulhados no parênquima fundamental e apresenta uma faixa contínua de colênquima angular subjacente às duas faces epidérmicas.

Nas análises fitoquímicas e farmacopéicas, a droga vegetal apresentou teor de umidade $=11,28 \pm$ $0,21 \%$, teor de cinzas totais $=16,27 \pm 0,47 \%$ e teor de cinzas insolúveis em ácido $=1,23 \pm 0,02 \%$. O extrato etanólico apresentou $\mathrm{pH}=6,5$, cor verde acastanhada, sabor mucilaginoso e teor de extrato seco $=15,43 \pm$ $0,43 \mathrm{~g} \%$, e resultou positiva a pesquisa de alcalóides, 
glicosídios flavônicos e esteróides e/ou triterpenóides. $\mathrm{O}$ extrato aquoso apresentou $\mathrm{pH}=7,0$, cor castanha, sabor mucilaginoso, teor de extrato seco $=23,33 \pm$ $0,33 \mathrm{~g} \%$, e revelou resultado positivo à pesquisa de glicosídios saponínicos, ácidos fixos e taninos condensados. A concentração de alantoína, respectivamente, nos extratos etanólico e aquoso foi de $1,05 \mathrm{~g} \%$ e $1,09 \mathrm{~g} \%$.

As características morfo-anatômicas observadas, bem como as análises fitoquímicas e farmacopéicas realizadas, contribuem na identificação farmacognóstica da folha de confrei, sendo aplicáveis ao controle de qualidade, além de fornecerem dados taxonômicos complementares à espécie vegetal.

\section{Material e Métodos}

A matéria vegetal foi coletada em junho de 2002, na região metropolitana de Curitiba - PR (25o 23' 03" S e 45o 07' 02" W), e a exsicata foi registrada sob número MBM 269350, no Herbário do Museu Botânico Municipal de Curitiba. Para a análise microscópica, as folhas foram fixadas em FAA $70^{4}$, conservadas em etanol a $70 \%{ }^{5}$, seccionadas à mão livre e coradas segundo microtécnicas usuais ${ }^{6,7}$. Para as análises fitoquímicas ${ }^{8,9}$ e farmacopéicas ${ }^{10}$, as folhas foram secas em estufa a $45 \pm 0,5^{\circ} \mathrm{C}$ e pulverizadas, em seguida foram preparados extratos etanólico a $70 \%$ e aquoso, na proporção de 20 $\%$ p/v pelo processo de maceração.

\section{Referências}

${ }^{1}$ Yunes, R.A.; Calixto, J.B. (orgs.). Plantas medicinais sob a ótica da química medicinal moderna. Chapecó: Argos, 2001. p.1-523.

${ }^{2}$ Font Quer, P. Plantas medicinales: el dioscórides renovado. 6. ed. Barcelona: Labor, 1980. p.549-550. ${ }^{3}$ Cruz, G.L. Dicionário das plantas úteis do Brasil. 5.ed. Rio de Janeiro: Bertrand, 1995. p.289-290.

${ }^{4}$ Johansen, D.A. Plant microtechnique. New York: MacGraw Hill Book, 1940.

${ }^{5}$ Berlyn, G.P.; Miksche, J.P. Botanical microtechnique and cytochemistry. Eames: Iowa State University, 1976.

${ }^{6} \mathrm{O}$ 'brien, T.P.; Feder, N.; Maccully, M.E. Polychromatic staining of plant cell walls by toluidine blue $O$. Protoplasma, Vienna, v.59, n.2, p.368-373, 1965.

${ }^{7}$ Roeser, K.R. Die Nadel der schwarzkiefermassenprodukt und kunstwerk der natur. Mikrokosmos, Stuttgart, v.61, n.2, p.33-36, 1962.

${ }^{8}$ Matos, J.M.D.; Matos, M.E.O. Farmacognosia: curso teórico-prático. Fortaleza: UFC, 1989.
${ }^{9}$ Moreira, E.A. Marcha sistemática de análise fitoquímica. Tribuna Farmacêutica, Curitiba, v.47, n.1, p.1-19, 1979.

${ }^{10}$ Farmacopéia Brasileira. 4. ed. São Paulo: Atheneu, 1988.

\begin{tabular}{l} 
* Autora para correspondência \\
\hline Profa. Dra. Tomoe Nakashima \\
Departamento de Farmácia \\
Universidade Federal do Paraná \\
Rua Prefeito Lothário Meissner 3400 \\
Jardim Botânico \\
CEP 80210-170 - Curitiba - PR \\
Email: tomeonak@ saude.ufpr.br
\end{tabular}

